\title{
Chert from the Vegamián Formation: A new raw-material supply source in the Cantabrian Mountains (NW Spain) during prehistory
}

\author{
Diego Herrero-Alonso ${ }^{1}$, Antonio Tarriño-Vinagre ${ }^{2}$, Ana Neira-Campos ${ }^{3}$, \\ Natividad Fuertes-Prieto ${ }^{3}$ \\ 1. Universidad de Salamanca, Salamanca, Spain. Email: dherreroalonso@usal.es \\ 2. Centro Nacional de Investigación sobre la Evolución Humana (CENIEH) Burgos, Spain. \\ Email: antonio.tarrinno@cenieh.es \\ 3. Área de Prehistoria, Universidad de León, León, Spain. Email: Neira-Campos: ana.neira.campos@unileon.es; \\ Fuertes-Prieto: n.fuertes@unileon.es
}

\begin{abstract}
:
This work provides the keys to the mineralogical and geochemical characterization of black chert from the Vegamián Fm. This formation crops out throughout the whole of the Cantabrian Zone (of Palaeozoic age), one of the geological zones of the Cantabrian Mountains (NW Spain). The geographical distribution of this formation is very wide, surfacing in the provinces of León, Asturias, Palencia and Cantabria.

This variety of chert had been included within the group generically known as 'black chert', a macrogroup including different types of chert that appear in different Palaeozoic formations in the area and which share a characteristic black colour at the macroscopic level. The characterisation presented here has enabled us to distinguish it from other varieties. In this study, Vegamián chert has been divided into two different groups depending on their textural, mineralogical, geochemical and thermal propierties. Type 1 , the most suitable for knapping, is characterized by high content in silica (>97\%), laminated matrix and, occasionally, ghost of radiolarians.

In addition, the characteristics specific to this chert make it suitable for lithic knapping processes. To confirm its use by prehistoric populations, this chert will be compared to that found in two Mesolithic sites, the caves of La Uña and El Espertín (León, south versant of the Cantabrian Mountains), the raw materials from which are currently under study.
\end{abstract}

Keywords: lithic raw materials; methodology; Carboniferous 'Black chert'; Mesolithic; Cantabrian Mountains

\section{Introduction}

The lithic raw materials exploited by humans during prehistory in the Palaeozoic area of the Cantabrian Mountains are mostly unknown (Arias Cabal et al. 2009; Tarriño et al. 2015). With the aim of determining the socio-economic relationship these prehistoric groups had

Published by the School of History, Classics and Archaeology, University of Edinburgh ISSN: 2055-0472. URL: http://journals.ed.ac.uk/lithicstudies/

This work is licensed under a Creative Commons Attribution 2.5 UK: Scotland License. 
with the environment they lived in, we have been undertaking research aimed at characterising fine-grained siliceous raw materials in the west-central area of the Cantabrian Mountains (in the north of the Iberian Peninsula). This will allow us to complete the potential lithological base of this area and therefore of available local resources so that the sourcing patterns by prehistoric populations of both local and exogenous raw materials can be analysed. To contrast the use of potential raw materials with those used by humans, we are studying the lithic industries from two Mesolithic sites: La Uña and El Espertín caves (León, in the Riaño area) (Fuertes Prieto 2004; Fuertes Prieto et al. 2010; Herrero 2014; Neira et al. 2015).

Siliceous raw materials composed of micro-cryptocrystalline quartz collected from these two sites have been divided into three main groups based on their macroscopic characteristics: black chert, radiolarite (both of local origin) and exogenous 'flint'. In this paper we will focus on one of the varieties from the first group, which is the most heterogeneous and the most abundant at the archaeological sites. Black chert refers to the group of black or dark grey fine/very fine-grained siliceous rocks emerging from the different Palaezoic (mainly from Carboniferous) geological formations occurs in the Cantabrian Mountains. Therefore, this term encompasses cherts of different geological origins whose main shared characteristic is their colour.

\section{Vegamián Formation}

There are numerous references to silicifications in the Palaeozoic formations of the Cantabrian Mountains. One of the most mentioned in the literature is the Vegamián Formation. This formation crops out on the northern edge of the Iberian Massif, inside the Cantabrian Zone, in the Tournaisian age (Martínez-Chacón et al. 1985) (Figure 1).

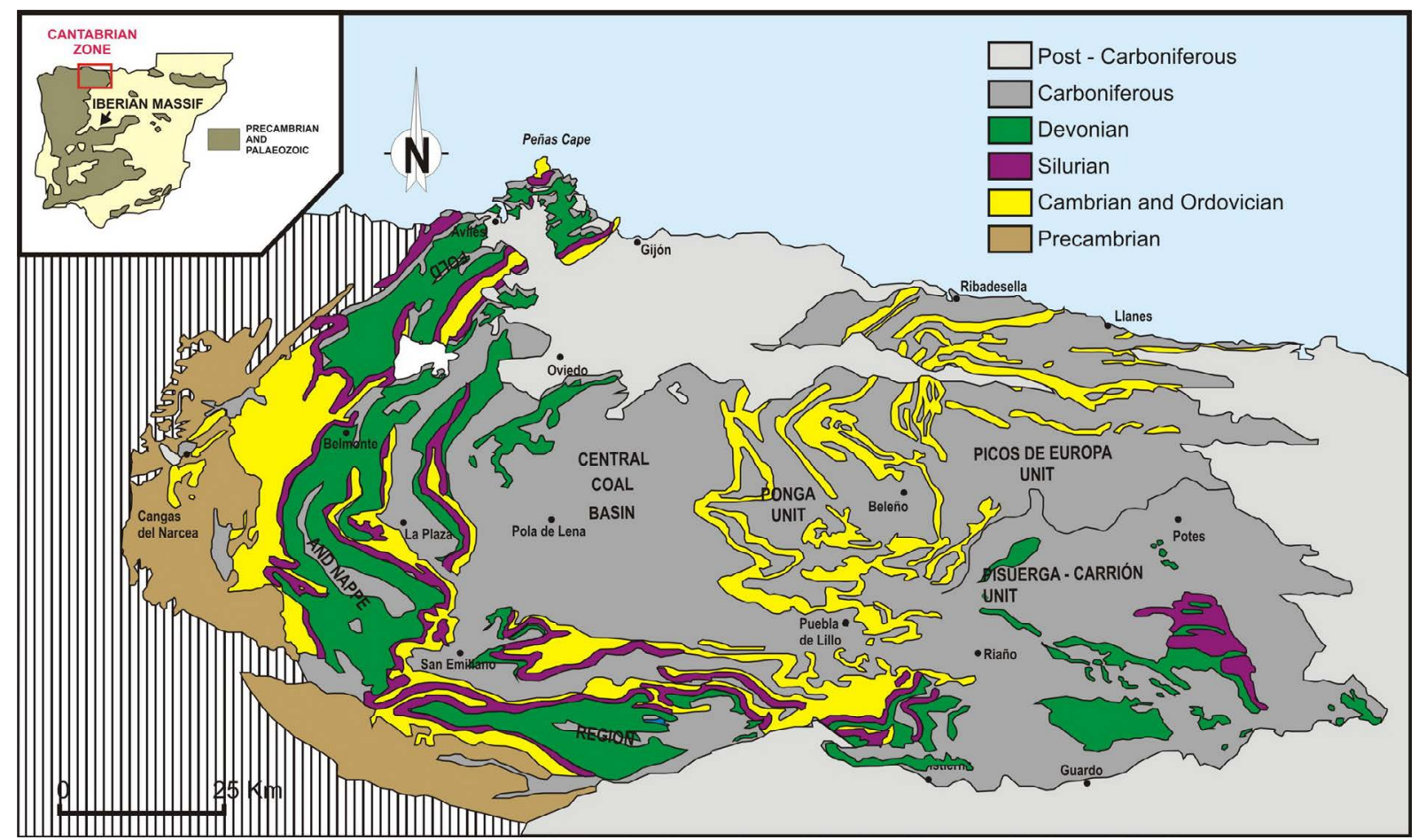

Figure 1: Geological units of the Cantabrian Zone modified from Julivert (1971).

The first stratigraphic studies of the Vegamián Formation were carried out by Comte (1959: 330), south of the eponymous village (León). He defined it as "15 mètres d'épaisseur, elle est formée de schistes noires anthraciteux renfermant quelques nodules silico-phosphatés 
dans lesquels je n'ai pu trouver de fossiles". This stratotype was 'drowned' with the construction of the Porma Reservoir in 1969, so Evers (1967) made another section on what is now the LE-331 (Bonar-Puerto San Isidro) road. The lithostratigraphy of the new section is described as: "thin layers of black shales and fine-grained argillaceous sandstones. At the base and top are concentrations of phosphatic nodules, while chert lenses can be found at various levels” (Evers 1967: 104) (Figure 2). However, Wagner et al. (1971) disagree with this definition, arguing that the final $8 \mathrm{~m}$ of the formation belong, in fact, to the Alba Formation wall, but dare not assure this given the erosion of the section, which made it impossible to clearly observed what had been described by Evers. Despite this setback, the stratotype opened up by Evers (1967) continues to be the stratotype in the study of the Vegamián Formation.

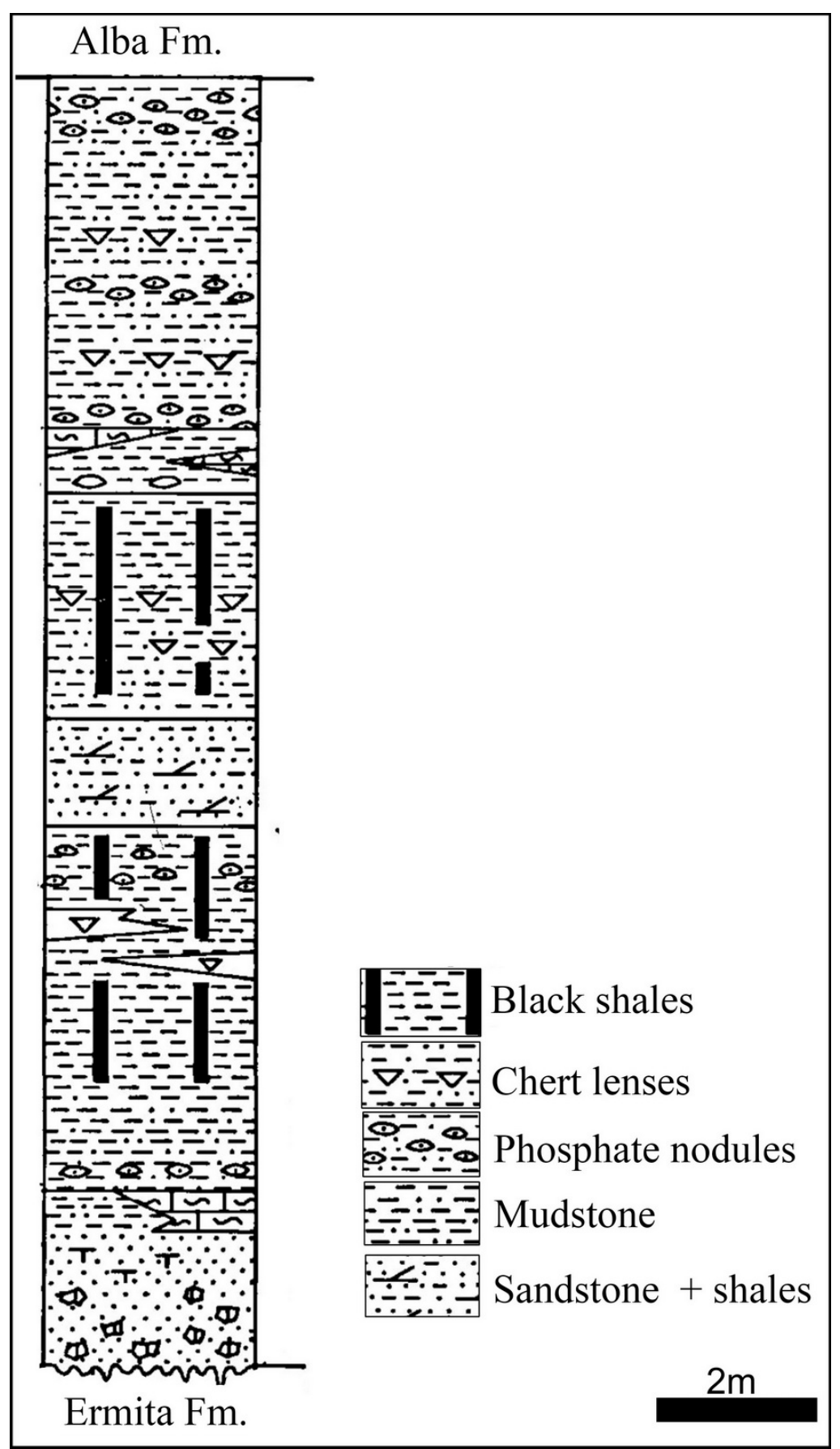

Figure 2: Stratigraphic column of the Vegamián Formation type section. (Based on Evers 1967). 
The black shales of Vegamián Formation was deposited in a low energy depositional environment, restricted and probably in anaerobic bottom conditions (Wagner et al. 1971).

Studying the Vegamián Formation entails a number of problems linked to its age and distribution compared to other nearby formations. The main issue is linked to the high degree of erosion it presents. It has disappeared from most parts as it is a softer layer than those adjacent to it, or because it has been covered by a large amount of materials that makes it impossible to make a stratrigraphic column (as noted earlier by Wagner et al. 1971). The parts where it is best noted are those which underwent erosion, but non-accumulation processes (such as steep slopes) or those being constantly renewed (such as rivers with torrential or variable flows cutting through mountains).

Another major problem is the thinness of the formation, as it appears in thin layers around $5 \mathrm{~m}$ in thickness, exceptionally up to $40 \mathrm{~m}$ in areas such as Cardaño de Arriba (Palencia). This means that, at times, it is not shown on maps (such as the outcrop found in the vicinity of La Uña, POL1, Figure 3) or it is only shown as a line in contact with another formation (Lobato et al. 1979). There have also been instances in which the Alba and Vegamián Formations have been represented together, such as in the MAGNA map number 103 (Alonso et al. 1988). On the other hand, the thinness of the formation has also led at times to an overrepresentation of its dimensions on the map, thus distorting its true dimensions. Lastly, part of the study area has been flooded by several reservoirs, making it difficult to study the sourcing from both the primary outcrops as well as the secondary deposits.

\subsection{Terminology: 'Chert’ from Vegamián Fm.}

The terminology used to describe the silicifications from the Palaeozoic area of the Cantabrian Mountains presents a problem when attempting to characterise them. This is due to the wide range of terms used to describe the rocks comprising this type of formations: black chert, flint, radiolarite, lydite, phtanite or even jaspe. Although in some cases the use of some of these terms is linked to the origins of these rocks, at other times the literature does not specified the reason behind the use of the term.

In the case of the Vegamián Formation, the silicifications have been described using a variety of terms, but mainly two: black chert (Savage \& Boschma 1980; Wagner et al. 1971) and lydite (Martínez-Díaz 1983; Rodríguez Fernández et al. 1983). Given the ambiguity arising from the use of two different terms to describe a single type of rock, we deem it necessary to specify the terminology in order to avoid confusion.

The term lydite is less commonly used when discussing this formation and its use has been imported from German researches, who worked in the region early 20th Century. Within this realm, a lydite is a variety of black chert formed by the accumulation of radiolarians, with a conchoidal fracture and emerging in strata (Randon \& Caridroit 2008). In addition, lithified slate found in this formation has also been termed lydite (Álvarez-Alonso et al. 2013).

The term lydite, however, is understood differently in the Iberian Peninsula and when mentioned in the literature refers to Palaeozoic black chert of unknown origin and characteristics (Tarriño 1998); that is to say, it is a very generic term, with a vaguer meaning than within the German tradition. In addition, in the Iberian Peninsula the term lydite, or touchstone, is more frequently associated with gemmology. Due to all the above, in this particular case we deem it appropriate to let go of this term.

The term chert, on the other hand, is the most frequently used both in the Spanish and English literature to refer to silicifications of the Vegamián Formation. We have therefore chosen to use this term in the present paper, which in no case has implications of a 
geochemical, mineralogical or textural nature, but simply follows the vocabulary of choice of geological studies of this area.

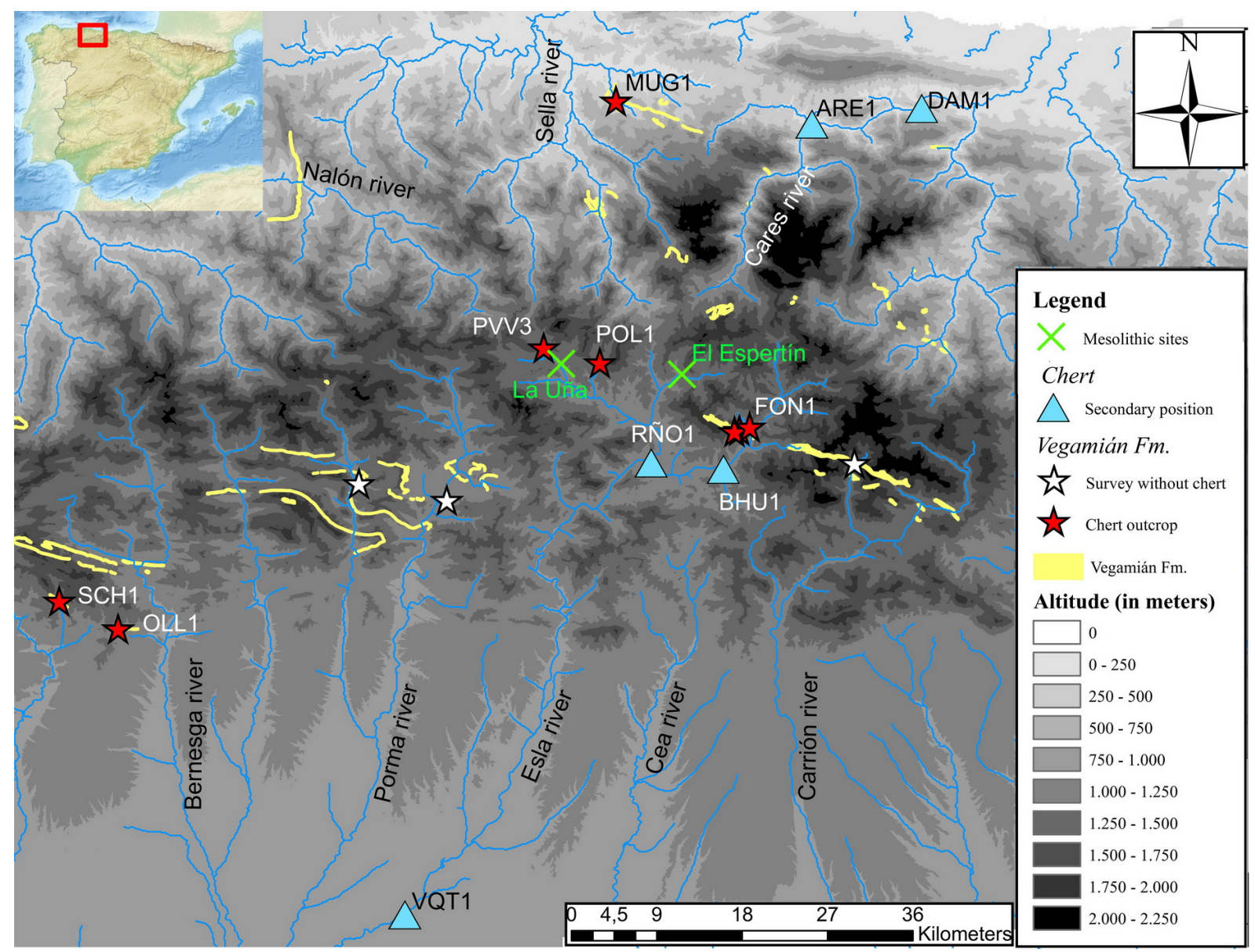

Figure 3: General distribution map of the Vegamián Formation in the Cantabrian zone. Red stars: chert outcrops in primary source. White stars: Vegamián Formation without chert. Triangles: secondary deposits of 'black cherts'. Crosses: archaeological sites. (Source: altitude maps are taken from Centro Nacional de Información Geográfica-CNIG; rivers from Infraestructura de Datos Espaciales de España-IDEE and geological distribution of Vegamián Fm. from Instituto Geológico y Minero de España- IGME).

\section{Materials and methods}

The methodology applied to develop the characterization of the Vegamián Formation includes 8 types of analyses. They are as follows.

\section{Bibliographic research:}

Review of geological literature with references to chert and locations of possible source areas from two main sources: the MAGNA series geological maps (E. 1:50.000) edited by Instituto Geológico y Minero de España (IGME), and works presented in specialist journals, conferences (Martínez-Díaz 1983) and other publications (Aramburu \& Bastida 1995; Bastida 2004; Suárez et al. 1994).

\section{Fieldwork:}

Using the data collected during the literature review, fieldwork was undertaken with the aim of locating the Vegamián Formation and to take chert samples. A total of 9 outcrops in a primary position and five in a secondary position were located as a result. Of the former only 
six contain chert. In terms of the contexts in a secondary position, we found cobbles matching those found in the Vegamián Formation, from the Esla (León) and Cares (Asturias) valleys. This phase is not finished as fieldwork is still ongoing. All materials collected during this phase of the project have been deposited in the lithoteque of the Laboratory of Prehistory at the University of León.

\section{Macroscopic analysis:}

50 samples from the different sources were taken into account (Table 1). The samples were analysed as in previous studies (Fuertes-Prieto et al. 2010; 2014; Herrero 2014), entailing the recording of six general attributes: colour (Munsell 2013), matrix (lamination, lenses, porosity, etc.) and inclusions (authigenic minerals, relict minerals, microfossils, etc.), structure (homogeneity of the pieces in terms of the occurrence of fracture planes, more irregular areas, etc.), appearance (gloss and transparency), cortex and alterations. Two stereo microscopes were used: a Nikon SMZ-1000 with magnifications in the 8-80x range, and an Olympus MSZ-71 between 6.5-45x.

Table 1: Origin and samples studied according to the different analytical procedures used. The outcrops are located in Figure 3.

\begin{tabular}{llccc}
\hline Reference & $\begin{array}{c}\text { Type of } \\
\text { source }\end{array}$ & $\begin{array}{c}\text { Macroscopic } \\
\text { Analysis } \\
\text { (no. of samples) }\end{array}$ & $\begin{array}{c}\text { Thin section } \\
\text { (no. of samples) }\end{array}$ & $\begin{array}{c}\text { XRD, XRF, ICP-OES, } \\
\text { TG-DSC } \\
\text { (no. of samples) }\end{array}$ \\
\hline FON 1 & Primary & 6 & 1 & 1 \\
MUG 1 & Primary & 6 & & \\
OLL 1 & Primary & 4 & 1 & 1 \\
POL 1 & Primary & 4 & 1 & 1 \\
PVV 3 & Primary & 4 & 1 & 1 \\
SCH 1 & Primary & 4 & 1 & 1 \\
ARE 1 & Secondary & 4 & & \\
BHU 1 & Secondary & 4 & 2 & 1 \\
DAM 1 & Secondary & 4 & & \\
RÑ 1 & Secondary & 2 & 1 & \\
VQT 1 & Secondary & 8 & 3 & \\
\hline
\end{tabular}

\section{Thin sections:}

Taking the variability observed macroscopically into account, 11 thin sections were made, five from primary sources and six from secondary contexts (Table 1). The petrographic analysis was carried out using two petrographic microscopes: a Kyowa model ME-POL2-B and an Olympus BX51.

The characterisation is divided into two parts:

i) The study of the matrix in order to define the mineralogical and textural composition of the samples under study. As for the texture, the size of the grain, homogeneity and its morphology have been defined. The appearance surfaces of unconformity, (joints, fractures) including information about the morphology, the angles between, and the mineral fillers.

ii) Study of the inclusions, divided into two types. The inorganic, such as, for example, authigenic and/or relict minerals, with information collected on their size and morphology. With regard to organic inclusions, various data were collected on the organic matter, the microfossils and other bioclasts. 


\section{X-Ray Difraction (XRD):}

Six samples were selected among the primary and secondary sources (Table 1) for the XRD analysis. These same samples also underwent XRF, ICP-OES, and TG-DSC. Each powder was subjected to X-ray powder diffraction, using a PANalytical X'PertPRO diffractometer system with $\mathrm{Cu} \mathrm{K \alpha}$ radiation ( $45 \mathrm{kV}$ and $40 \mathrm{~mA}$ excitation). The initial angle is $5^{\circ} 2 \theta$ and the final angle is $70^{\circ} 2 \theta$, with an angle increase of $0.02^{\circ} 2 \theta$. In our case, the determinations undertaken are semi-quantitative, calculated from the Reference Intensity Ratio factors (or RIR factors) of the different minerals (Chung 1974). The mineralogical identification was carried out using the X'Pert HighScore Plus (v3.0) software by PANalytical.

\section{X-Ray Fluorescence (XRF):}

The geochemical analysis was carried out using two different and complementary techniques. X-Ray Fluorescence was used for the major elements. For the undertaking of the sample analysis, beads were prepared by homogeneously mixing $0.5 \mathrm{~g}$ of powdered sample with $5.0 \mathrm{~g}$ of flux (lithium metaborate - lithium tetraborate in a 34\%-66\% ratio) and then melted in a Pt-Au crucible in a Perl X3 PANalytical automated glass bead casting machine. To obtain the loss on ignition the sample is heated up to $1050^{\circ} \mathrm{C}$. Subsequently the samples were analysed in a wavelength dispersive X-ray fluorescence spectrometer (WDXRF), PANalytical Axios model, with a $4 \mathrm{~kW}$ Rh tube.

\section{Inductively Coupled Plasma Optical Emission Spectrometry (ICP-OES):}

All samples have been ground into a zirconium tray at $28 \mathrm{~Hz}$ for 10 minutes. Later, they were subjected to microwave digestion (HNO3 + HF) and neutralizate with H3BO3. The analysis were be done with a spectrometer Perkin Elmer ICP OES 5300 DV in dual plasma mode. The samples were introduced into a thermostat cyclonic spray chamber at $25^{\circ} \mathrm{C}$ and a nebulizer type GemCone. Concentration values are expressed in $\mu g$ of chemical element per gram of solid sample ( $\mu \mathrm{g}$ g-1).

\section{Thermogavimetry with Differential Scanning Calorimetry TG-DSC:}

Finally, the use of thermal analysis using a technique that combines Thermogavimetry (TG) with Scanningg Differential Calorimetry (DSC), is suggested.

Thermogavimetry (TG) is a technique in which a sample, of which the mass is known, is subjected to a change in controlled temperature, controlling the mass to know the exact moment in time and temperature it varies (Hatakeyama \& Liu 1998: 4). This lets us know what substance may have been the cause of this variation.

Differential Scanning Calorimetry (DSC) is a technique that subjects two samples (one a reference, of which its thermal behaviour is usually known, and the sample to be analysed) to a gradual and controlled temperature change. During the time the samples are undergoing this change, the exact temperature of each is measured. The reference sample will always follow a specific and well-known pattern, while the other sample will vary its temperature depending on the physico-chemical reactions (endothermic and/or exothermic) taking place. With the data from both readings one obtains the heat-flow, which is the difference between the temperature of the sample and the reference at the same point in time (Hatakeyama \& Liu 1998: 19).

In this case, the use of this joint technique is suggested in order to determine the percentage of volatiles present within the sample and to identify them. This new methodology allows us to complete a portion of the information we did not know about when using other 
analytical methods (as in the XRF with the L.O.I.). These analyses were performed in alumina crucibles using a TG-DSC TA Instruments Q600 with a program that starts at room temperature until it reaches $1100^{\circ} \mathrm{C}$, at a rate of $20^{\circ} \mathrm{C} / \mathrm{min}$. Lastly, two measurements were taken for each of the samples, one by means of air insertion $(100 \mathrm{ml} / \mathrm{min})$, the other in a pure $\mathrm{N}$ atmosphere (purged and subsequently introduced to $100 \mathrm{ml} / \mathrm{min}$ ). Taking measurements in two different atmospheres provides access to the contents of organic matter which volatilises.

\section{Chert outcrops}

\subsection{Primary position}

We have already discussed the difficulties faced when trying to locate the Vegamián Formation, especially due to the erosional processes undergone by it and its thinness (Figure 4A). In Figure 3 the wide geographic distribution of the formation can be observed, both on the north and south versants of this part of the Cantabrian Mountains, although it is very uneven and discontinuous. For now we have pinpointed nine locations for this formation, although the occurrence of chert has only been noted in six of them. These primary outcrops are all very similar; chert appears in centimetric strata, between 5-15 cm, although occasionally and exceptionally these can be as thick as $20 \mathrm{~cm}$, with some interbedded shales. The strata are separated by natural fractures perpendicular to the sedimentation plane, forming lineal edges and right angles, giving rise to rectangular-shaped blocks.

These outcrops are located in different geographical contexts: road (OLL1, MUG1; Figure 4B) and Becenes River (POL1) cuts (Figure 4C), steep slopes (SCH1 and PVV3, Figure 4D), or areas close to mountain tops (FON1 is found 1,800 meters about sea levelm.a.s.l.; Figure $4 \mathrm{E}$ and F). In these contexts, chert, more resistant to erosion than shales, stands out on the ground and is thus easily identifiable, although sometimes difficult to access. In addition, most of these strata are of poor quality for knapping, mainly due to the high number of internal fractures.

\subsection{Secondary position}

The analysis of the raw materials collected from the river basin terraces is of vital importance for this geographical area for mainly two reasons: i) they are high-mountain contexts, in which the outcrops in a primary position are sometimes difficult to access, as mentioned above; ii) these Palaeozoic cherts have undergone numerous destructive processes, both internal (faults, fold) and external (erosion, cryoclast).

Therefore, the advantages of cobbles collected from secondary as opposed to primary positions are: i) improved accessibility to these contexts; ii) better potential quality for knapping because these have been transported, accumulated and selected by erosion and riverflow transport processes, thus eliminating the weaker parts and leaving behind those homogeneous parts with a more compact and resistant conchoidal fracture.

However, when studying chert from secondary positions two issues arise. The first relates to the fact that the terraces and river basins that make up this type of contexts receive inputs from the various geological formations present in the source areas of these water systems. Therefore, black chert nodules from other formations other than the Vegamián, generally very similar amongst them at the macroscopic level, appear simultaneously. The second major drawback are anthropic modifications, especially those caused by the reservoirs present in the river headwaters of rivers and in their modern channeling. So far, during the survey of these contexts we have located cherts whose macroscopic characteristics are compatible with those from the Vegamián Formation on different terraces of the Esla and 
Cares, particularly in their headwaters and middle sections. These are rounded, suitably-sized nodules (larger than $10 \mathrm{~cm}$ on their shortest side) and suitable for lithic knapping.
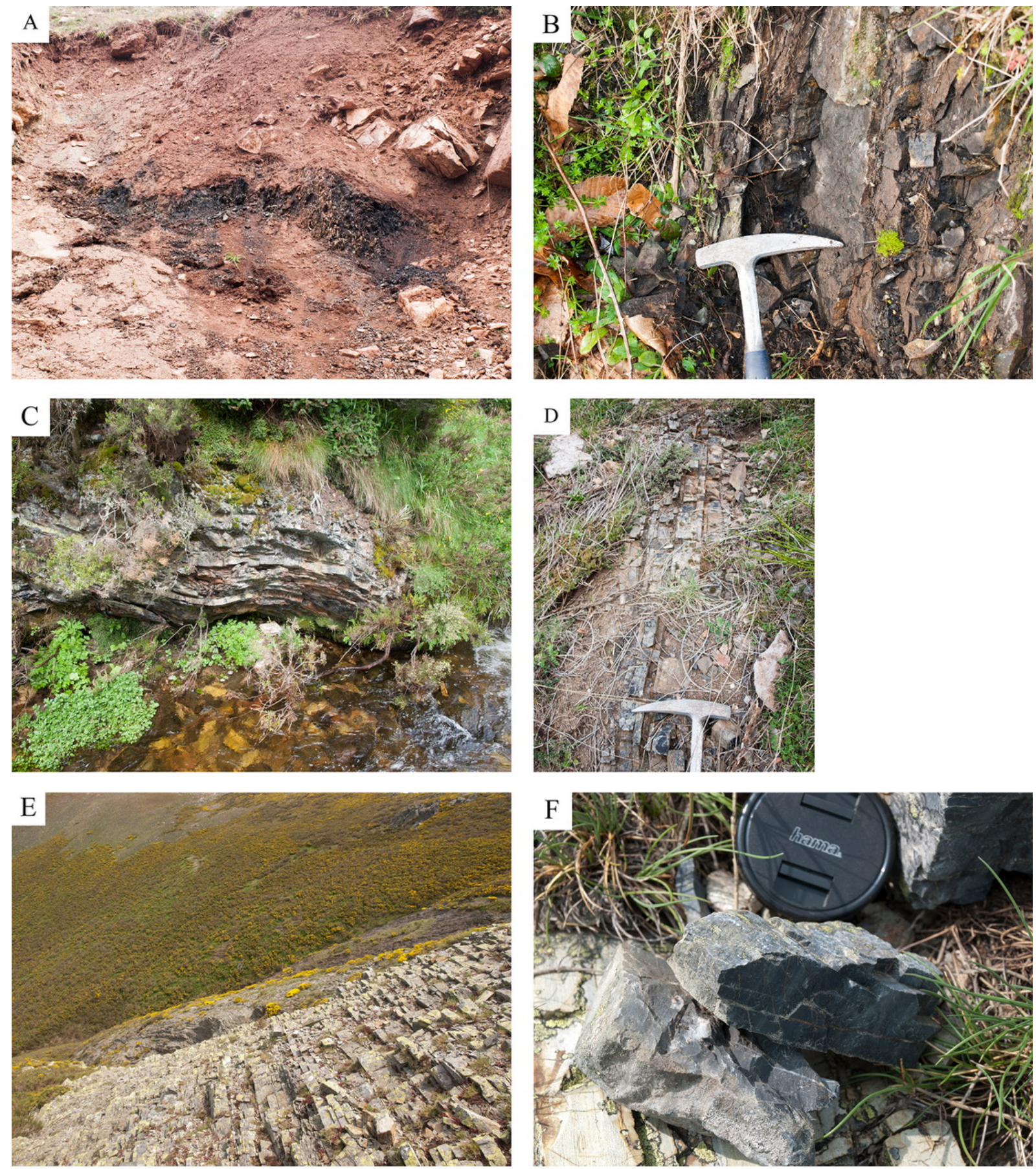

Figure 4: Outcrops of Vegamián formations: A) Section without chert, completely covered in materials originating from the dissolution of the Alba Formation. B) Outcrop MUG1 covered by vegetation, identified using the Marcos (1967) stratigraphic diagram. C) Chert outcrop in the Polvoredo (POL1) stream section with no mention of the formation in the MAGNA. D) Outcrop SCH1, with chert standing out in relation to the rest of the dissolved layer. E) Outcrop FON1, at the top of a mountain with asteep slope (ca 1800 m.a.s.l.). F) Detail of chert nodule recovered from a primary position (FON1).

\section{Results}

The samples studied and the analyses these underwent are presented in Table 1. 


\subsection{Macroscopic analysis}

Two types have been identified macroscopically (Type 1 and 2) and these are described in Table 2. Type 1 includes samples originating from both primary and secondary outcrops. Type 2 originates solely from primary sources.

Table 2: Macroscopic characteristics of the analysed cherts.

\begin{tabular}{|c|c|c|c|}
\hline \multicolumn{2}{|c|}{ 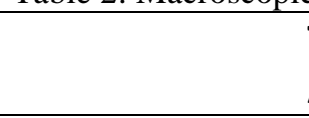 } & $\begin{array}{l}\text { Type 1: FON1, VQT1, BHU1, DAM1, } \\
\text { ARE1, RÑO1, MUG1 }\end{array}$ & $\begin{array}{l}\text { Type 2: PVV3, SCH1, POL1, } \\
\text { OLL1 }\end{array}$ \\
\hline \multicolumn{2}{|l|}{$\begin{array}{l}\text { Colour and } \\
\text { pattern } \\
\text { distribution }\end{array}$} & $\begin{array}{l}\text { Very dark grey-black (GLEY1 3/N a } \\
2.5 / \mathrm{N} \text {, Munsell Color 2013) with a } \\
\text { marked lamination within the same } \\
\text { colour range, varying solely in its } \\
\text { intensity (Figure } 5 \mathrm{~A} \text { ). }\end{array}$ & $\begin{array}{l}\text { Deep black (GLEY1 } 2.5 / \mathrm{N} \text { ), very } \\
\text { homogeneous, with no visible } \\
\text { lamination. }\end{array}$ \\
\hline \multicolumn{2}{|c|}{ Appearance } & Matte and opaque. & Matte and opaque. \\
\hline \multirow[t]{2}{*}{$\begin{array}{l}\text { Matrix } \\
\text { and } \\
\text { inclusions }\end{array}$} & 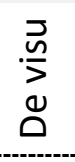 & $\begin{array}{l}\text { Has a slightly coarser and rougher to the } \\
\text { touch grain than Type } 2 \text {. }\end{array}$ & $\begin{array}{l}\text { No internal components can be } \\
\text { discerned. The grain is slightly } \\
\text { thinner than that of Type } 1 .\end{array}$ \\
\hline & 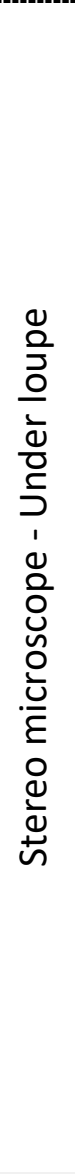 & $\begin{array}{l}\text { Lenticular lamination (Figure 5B), } \\
\text { sometimes parallel (this difference in } \\
\text { lamination, although very subtle, is the } \\
\text { only macroscopic difference between } \\
\text { the VQT1, ARE1 and DAM1 nodules, } \\
\text { which is further discussed in the thin- } \\
\text { section section below; Figure 5C). } \\
\text { Very few inclusions are noted, just a few } \\
\text { isolated organic matter spots and some } \\
\text { idiomorphic rhomboidal crystals } \\
\text { authigenic (calcite/dolomite). } \\
\text { Radiolarians have not been documented } \\
\text { within this type. } \\
\text { Some fractures can be seen, although } \\
\text { well cemented, meaning that a good } \\
\text { quality conchoidal fracture could be } \\
\text { produced. } \\
\text { There is a heavy occurrence of } \\
\text { dolomites within the MUG1 samples. } \\
\text { Pending confirmation from the thin- } \\
\text { section portion of the study, these have } \\
\text { been included within this group for the } \\
\text { time being. }\end{array}$ & $\begin{array}{l}\text { Intense black matrix. Although it } \\
\text { is not easy to see, there is } \\
\text { lenticular lamination (Figure } \\
\text { 5D), which becomes more } \\
\text { visible when the surface has } \\
\text { been subjected to modification } \\
\text { processes. In these cases, } \\
\text { besides the lamination, the } \\
\text { presence of some possible } \\
\text { radiolarians in a poor state of } \\
\text { preservation can also be noted. } \\
\text { In terms of the fractures, they } \\
\text { are much more abundant and } \\
\text { less cemented, which hinders } \\
\text { the knapping processes and } \\
\text { makes of this variety a less } \\
\text { suitable raw material. }\end{array}$ \\
\hline \multicolumn{2}{|l|}{ Cortex } & \multicolumn{2}{|c|}{$\begin{array}{l}\text { Primary position nodules: very smooth cortices, similar to host rocks as } \\
\text { they do not change in excess (Figure } 4 \mathrm{E} \text { ). They usually lighten slightly } \\
\text { toward grey tones. } \\
\text { Secondary position nodules: very fine fluvial cortex, slightly lighter, but } \\
\text { very similar to the matrix (Figure } 4 \mathrm{~F} \text { ). }\end{array}$} \\
\hline \multicolumn{2}{|l|}{ Alteration } & \multicolumn{2}{|c|}{$\begin{array}{l}\text { Alterations such as white patina on the samples under study has not been } \\
\text { noted. }\end{array}$} \\
\hline
\end{tabular}


All these characteristics make of these samples, especially those from Type 1, a suitable raw material for lithic knapping activities.
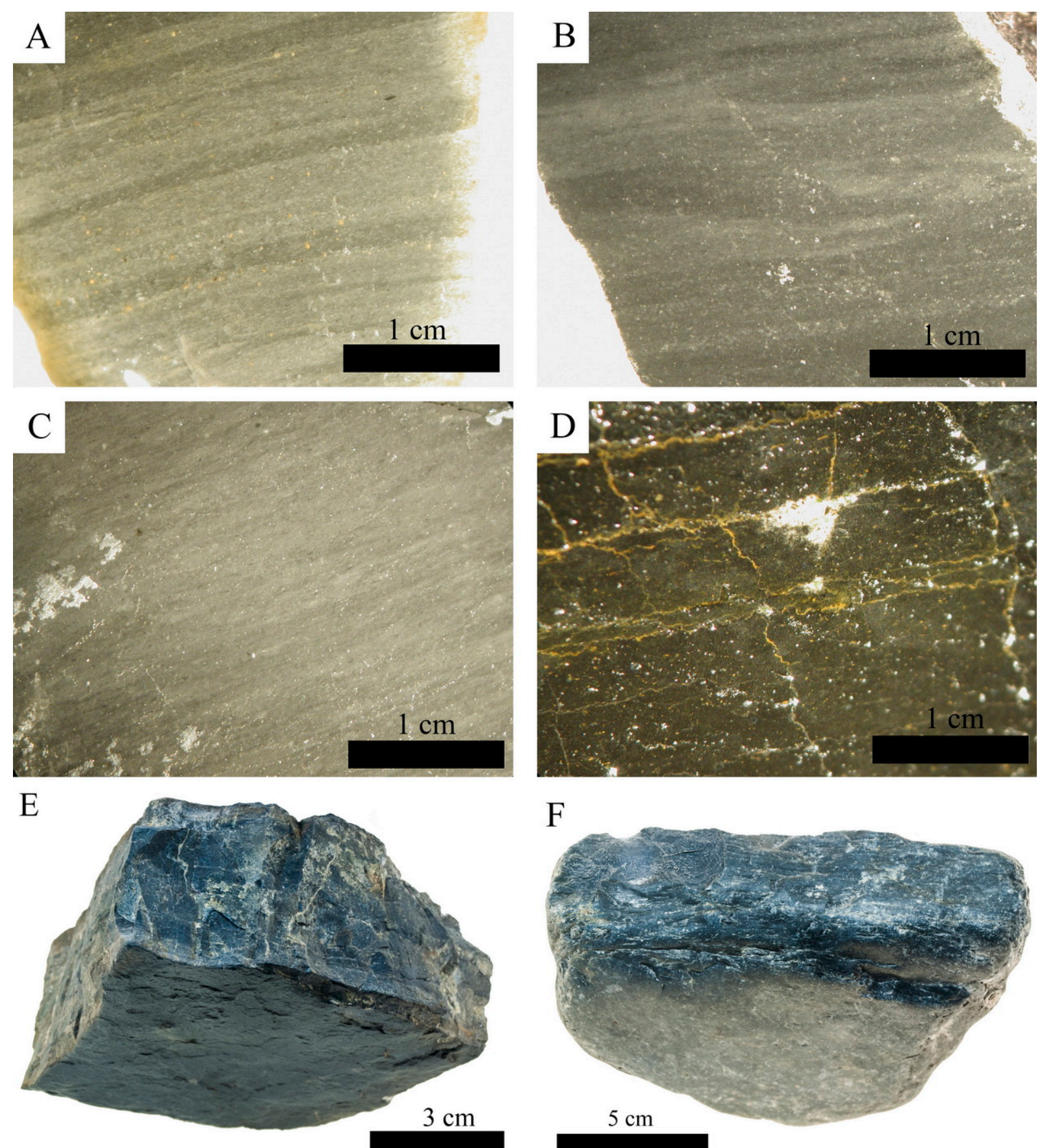

Figure 5: Different matrix from chert of Vegamián: A) Matrix (20x) of sample FON 1-8. The typical lenticular lamination on this particular variety can be seen here. B) Matrix (20x) of sample FON 1-9. The presence of lenticular lamination can be noted C) Matrix (20x) of sample VQT1-9. D) Matrix (20x) of sample SCH1-1. The stylolites vertical to the sedimentation plane can be seen here. E) Block from MUG1. The cortex is very smooth, similar to its host rock. F) Nodule from secondary position (BHU1). The fluvial cortex is highly developed, but colour is very similar.

\subsection{Thin section}

In thin section analyses, the matrix is a microquartz (smaller than $30 \mu \mathrm{m}$ ) and cryptoquartz (smaller than $2 \mu \mathrm{m}$ ) matrix with lenticular lamination due to the content of organic matter (Figure 6A). 
A key element is the occurrence, although not too numerous, of radiolarians, unlike in the case of some of the radiolarites from the Alba Formation (Fuertes Prieto et al. 2010, Straus et al. 1986). Most are ghost, with an average size of $150 \mu \mathrm{m}$, but varying generally between 100-200 $\mu \mathrm{m}$ (Figure 6B and 6C). They can take two forms, depending on the outcrop, spherical or ellipsoidal with the greater radius parallel to the sedimentation plane (Figure 6D), although it has not been possible to characterise them. The only reference in the literature to radiolarians in this geological point in time on the Cantabrian Zone mentions the Alba Formation (Kanis 1955), where Cenellipsis (order Spumellaria) is mentioned.

A second key element to differentiate these cherts to other Palaeozoic ones is through the presence of stylolites (Figure 6D). These develop perpendicularly to the sedimentation plane, although in the VQT1 samples these are parallel.

The occurrence of fractures is a recurring theme. In this case, they are a system of conjugated fractures, with, in general, angles closer to $60^{\circ}$, filled with quartz (both in mosaic and fibrous forms) and hematites (Figure 6E). Fractures perpendicular to the sedimentation plane are generally more developed.

We can also note the occurrence of two new generation minerals (authigenic), with pyrite $\left(\mathrm{FeS}_{2}\right)$ being the most relevant here and falling into two different size groups: those closer to $20 \mu \mathrm{m}$ and those closer to $100 \mu \mathrm{m}$ (Figure 6F). Lastly, there is a symbolic presence of rhombic idiomorphic crystals of dolomite within the $50-100 \mu$ m range, especially amongst the Type 2 cherts.

With all these data we have been able to differentiate between two types of black chert within the Vegamián Formation, which correspond to those identified at the macroscopic level.

- Type 1 is the most siliceous, with a micro-cryptocrystalline quartz matrix, as well as possessing all the characteristics previously mentioned. Samples FON1-1 (primary position), BHU1-6 and BHU1-2 (secondary position) fall within this category.

- Type 2 has a smaller percentage of quartz compared to other materials within the matrix, making them increasingly opaque. Within this variety, radiolarians are more abundant, are more complete and slightly ellipsoidal. The organic matter content is very high within some of the samples, so they are completely opaque in thin section, making it possible to distinguish only between the ghosts of the radiolarians and some detrital quartz. Samples PVV-3, POL1-1, OLL1-1 and SCH1-1 (all in a primary position) fall within this category.

The samples originating from secondary positions, RÑO1-1 and VQT1, macroscopically similar to the Type 1 chert from Vegamián, show marked differences from this kind in its thin section form. The main difference is the lamination produced by phyllosilicates and feldspars, more parallel than lenticular; the occurrence of more and complete radiolarians, and the formation of both pyrites as well as authigenic dolomites $100 \mu \mathrm{m}$ in size. Therefore, this group of black cherts in a secondary position is different to the characteristic Vegamián Formation ones.

\subsection{XRD}

The major element is quartz, representing over $90 \%$ in all cases except sample BHU1-2. Within the minor element groups felspars and micas represent less than $1 \%$ of the total. Lastly, dolomite, pyrite and hematite were found as trace elements. The XDR analysis has not enabled us to correctly distinguish between the different varieties, although some differences can be observed in their diffractograms. In terms of variety 1 , it has a much smaller number of impurities than does type 2, whereas felspars and micas are common in the latter. Based on the XDR, and given the small number of samples we have available, not many differences have been observed between the Vegamián type 2 chert and the VQT sample (Table 3). 

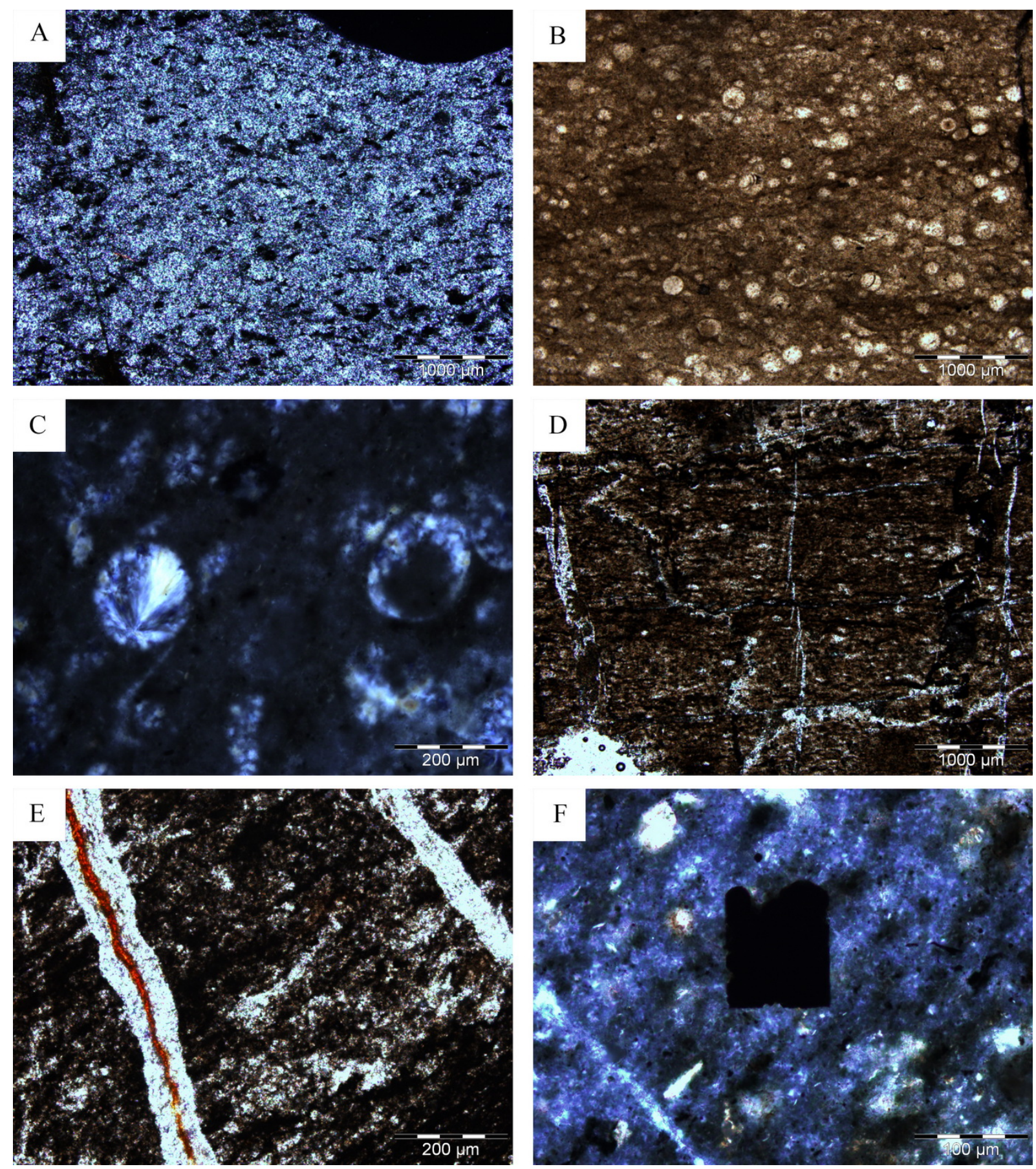

Figure 6: Microscopic characteristics of Vegamián chert: A) Matrix of a Vegamián Type 1 chert at 40x (FON11 ; cross-polarized light/xpl). It is mostly comprised of quartz, with some inclusions of organic matter. It is difficult to distinguish the radiolarians in polarized light. (scale bar $=1000 \mu \mathrm{m}$ ) B) Matrix of black laminated chert at 40x (RNOO1FON11; plane-polarized light/ppl). A high radiolarian content can be noted. (scale bar = $1000 \mu \mathrm{m}) \mathrm{C}$ ) Image of two radiolarians filled with fibrous quartz in a chert at 200x (RÑO1, xpl). (scale bar $=200$ $\mu \mathrm{m}) \mathrm{D})$ Matrix at 40x (OLL1-1; ppl). Vertical stylolites can be noted as well as the little transparency of the thin section. (scale bar $=1000 \mu \mathrm{m})$ E) Fracture of a chert filled with quartz and hematite (200x) (POL1-1; ppl). (scale bar $=200 \mu \mathrm{m}) \mathrm{F}$ ) Detail of a pyrite at 500x (OLL1-1; xpl). (scale bar $=100 \mu \mathrm{m})$

Finally, two special cases must be noted. On the one hand, sample BHU1-2 presents a high amount of minerals from the chlorite group, around $10 \%$ based on the semi-quantitive XRD analyses, resulting from the alteration of ferromagnesian minerals such as micas, pyroxenes, etc. On the other hand, in sample POL1-1, the presence of apatite has been identified, with a high P content (below 1\%), as can be seen in the XRF (Table 4). 
Table 3: Major, minor and trace elements in XRD.

\begin{tabular}{|l|c|c|c|c|c|c|c|c|}
\hline Sample & Quartz & Feldspar & Mica & Chlorite & Dolomite & Pyrite & Apatite & Hematite \\
\hline OLL1-1 & $>90 \%$ & $<1 \%$ & $<1 \%$ & - & Trace & Trace & - & - \\
\hline SCH1-1 & $>90 \%$ & $<1 \%$ & $<1 \%$ & - & - & Trace & - & Trace \\
\hline POL1-1 & $>90 \%$ & - & - & - & - & Trace & $<1 \%$ & - \\
\hline VQT1-1 & $>90 \%$ & $<1 \%$ & $<1 \%$ & - & - & Trace & - & - \\
\hline BHU1-2 & $>80 \%$ & Trace & - & $10 \%$ & Trace & - & - & Trace \\
\hline FON1-1 & $>95 \%$ & Trace & Trace & - & - & - & - & - \\
\hline
\end{tabular}

Table 4: XRF analysis of major and minor elements.

\begin{tabular}{|lllllllllllll|}
\hline Sample & $\mathrm{SiO}_{2}$ & $\mathrm{Al}_{2} \mathrm{O}_{3}$ & $\mathrm{Fe}_{2} \mathrm{O}_{3}$ & $\mathrm{MnO}$ & $\mathrm{MgO}$ & $\mathrm{CaO}$ & $\mathrm{Na}_{2} \mathrm{O}$ & $\mathrm{K}_{2} \mathrm{O}$ & $\mathrm{TiO}_{2}$ & $\mathrm{P}_{2} \mathrm{O}_{5}$ & $\mathrm{SO}_{3}$ & LOI \\
\hline & $(\%)$ & $(\%)$ & $(\%)$ & $(\%)$ & $(\%)$ & $(\%)$ & $(\%)$ & $(\%)$ & $(\%)$ & $(\%)$ & $(\%)$ & $(\%)$ \\
\hline OLL1-1 & 92.53 & 2.54 & 0.57 & $\leq \mathrm{LD}$ & 0.23 & 0.41 & 0.37 & 0.43 & 0.09 & 0.12 & 0.06 & 2.64 \\
\hline SCH1-1 & 91.68 & 2.58 & 0.80 & $\underline{L L}$ & 0.22 & 0.52 & 0.28 & 0.48 & 0.11 & 0.27 & 0.03 & 3.02 \\
\hline POL1-1 & 93.84 & 0.68 & 0.94 & $\underline{L L}$ & 0.51 & 1.07 & 0.06 & 0.06 & 0.02 & 0.99 & 0.04 & 1.78 \\
\hline VQT1-1 & 91.42 & 4.36 & 1.03 & $\underline{L L}$ & 0.36 & 0.08 & 0.58 & 0.73 & 0.21 & 0.02 & $\leq L \mathrm{LD}$ & 1.21 \\
\hline BHU1-2 & 84.46 & 4.66 & 6.00 & 0.12 & 2.07 & 0.18 & 0.12 & 0.11 & 0.18 & 0.05 & $\leq L \mathrm{LD}$ & 2.05 \\
\hline FON1-1 & 97.29 & 1.30 & 0.20 & $\underline{L L}$ & 0.06 & 0.09 & 0.18 & 0.25 & 0.06 & 0.05 & $\leq L \mathrm{LD}$ & 0.50 \\
\hline
\end{tabular}

\subsection{XRF}

The analysis of major elements via XRF confirms the high quartz content, around 91.96 $\%$ of the total sample, and ranging between $84.46 \%$ and $97.23 \%$. The percentage of calcite is very low (not identified in XRD). The Ca found in sample POL1-1, together with $\mathrm{P}$, are compatible with the presence of apatite.

As for $\mathrm{Ca}$ and $\mathrm{Mg}$, there are differences between the Type 1 and Type 2 cherts and the VQT1-1 sample. Whereas in Type 1 and VQT1-1 the calcium content is close to symbolic, within the Type 2 its occurrence is greater, as is the case with the magnesium. The high content of $\mathrm{Mg}$ in relation to $\mathrm{Ca}$ in sample BHU1-2, however, is striking. This amount of $\mathrm{Mg}$ is not directly linked to the dolomite, but instead to the chlorite present within the sample.

\subsection{ICP-OES}

The ICP-OES analysis has enabled us to group the samples in terms of their minority and trace elements (Figure 7 and Table 5). The amount of Al is quite significant in all of the samples, and $\mathrm{K}$ and $\mathrm{Na}$ are also well represented, which is very significant and is due to the presence of feldspars and aluminosilicates. These three elements, however, are more abundant in sample VQT1-1, and this greater abundance is one of its distinguishing features.

The Fe content differs depending on the sample. There is a small amount within the Type 1 cherts, and this is consistent with the formation of small-sized authigenic pyrites. This element increases within the Type 2 cherts, and this is linked to the filling of fissures, which often contain traces of hematites and other iron oxides. The BHU1-2 sample has the greatest content of this metal due to the existence of chlorite as an alteration mineral, the occurrence of which has been later confirmed through the thin section. This is not characteristic of this chert given it only appears in this particular sample. The VQT1-1 sample has similar amounts of Fe to those in Type 2 cherts, but, in this case, this is due to the formation of authigenic pyrites and not the filling of the fissure with hematites. 


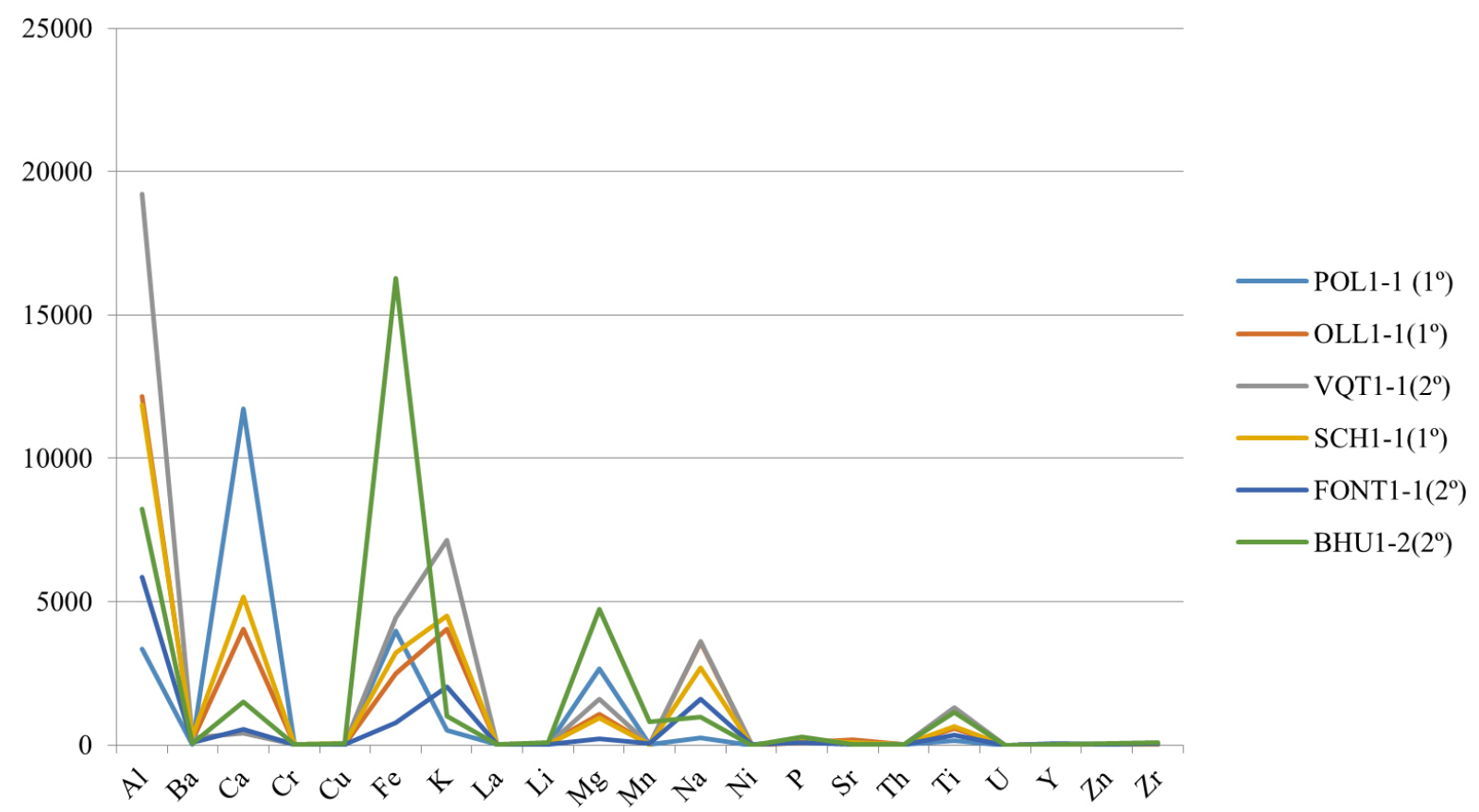

Figure 7: Graphic of the elemental content from the samples analysed via ICP-OES. Quantities are in ppm.

Table 5: ICP-OES samples results. Quantities are in ppm. The original contex of each reference is noted in the sample name: $1^{\circ}$ for primary source, $2^{\circ}$ for secondary deposits.

\begin{tabular}{|c|c|c|c|c|c|c|}
\hline & \multicolumn{6}{|c|}{ Samples } \\
\hline & OLL1-1(1ㅇ) & SCH1-1(19) & POL1-1 (1ㅇ) & VQT1-1(2ㅇ) & BHU1-2(2) & FON1-1(10) \\
\hline $\mathrm{Al}$ & 12143 & 11850 & 3353 & 19198 & 8235 & 5846 \\
\hline $\mathrm{Ba}$ & 141.0 & 294.1 & 9.5 & 251.8 & 35.8 & 76.9 \\
\hline $\mathrm{Ca}$ & 4036 & 5149 & 11715 & 428 & 1510 & 532 \\
\hline $\mathrm{Cr}$ & 13.9 & 29.1 & 13.3 & 20.9 & 33.3 & 6.1 \\
\hline $\mathrm{Cu}$ & 17.4 & 42.0 & 0.7 & 17.3 & 44.9 & 25.7 \\
\hline $\mathrm{Fe}$ & 2488 & 3214 & 3974 & 4449 & 16284 & 765 \\
\hline K & 4044 & 4507 & 524 & 7141 & 1019 & 2042 \\
\hline La & 3.72 & 3.89 & 3.77 & 4.58 & 20.53 & 4.83 \\
\hline Li & 39.85 & 29.14 & 5.77 & 12.50 & 94.62 & 1.21 \\
\hline $\mathrm{Mg}$ & 1086 & 948 & 2654 & 1612 & 4739 & 213 \\
\hline $\mathrm{Mn}$ & 24.7 & 12.8 & 4.1 & 17.5 & 820.1 & 63.3 \\
\hline $\mathrm{Na}$ & 3581 & 2702 & 249 & 3600 & 989 & 1609 \\
\hline $\mathrm{Ni}$ & $<3.4$ & $<3.3$ & $<3.3$ & 3.4 & $<3.3$ & 7.2 \\
\hline$P$ & 90 & 167 & 115 & 110 & 288 & 89 \\
\hline Sr & 192 & 88 & 41 & 73 & 22 & 25 \\
\hline Th & 2.0 & 2.0 & 2.3 & 2.8 & 6.3 & 3.0 \\
\hline $\mathrm{Ti}$ & 580 & 635 & 160 & 1309 & 1140 & 356 \\
\hline U & 0.3 & 0.2 & $<0.1$ & 0.3 & 0.4 & $<0.1$ \\
\hline Y & 4.7 & 6.3 & 4.1 & 4.4 & 9.1 & 39.6 \\
\hline $\mathrm{Zn}$ & 17.2 & 32.2 & $<0.4$ & 13.1 & 48.8 & 4.6 \\
\hline $\mathrm{Zr}$ & 32 & 34 & & 63 & 72 & 38 \\
\hline
\end{tabular}




\subsection{TG-DSC}

With the thermogravimetric analyses we can get approximation of the organic matter and water contents. In the case of the organic matter, the Type 2 chert samples (OLL1-1, SHC1-1 and POL1-1), more opaque in thin section, are those with the highest content (between $0.73 \%$ and $1.18 \%$ ), compared to the other three chert samples (minor of $0.05 \%$ ).

The water in the samples can also be measured, although not as easily given its variability. Besides superficial water, we can also find compositional water. However, the differences between them must be confirmed by future analyses. The water estimates again supports the division of the chert into two groups, given Type 2 chert is more hydrated (between $1.2 \%$ and $1.8 \%$ ) than Type $1(0.4 \%)$ (Figure 8). In the case of the VQT1 sample, it once again shows differences with regard to the rest of the Vegamián chert samples.

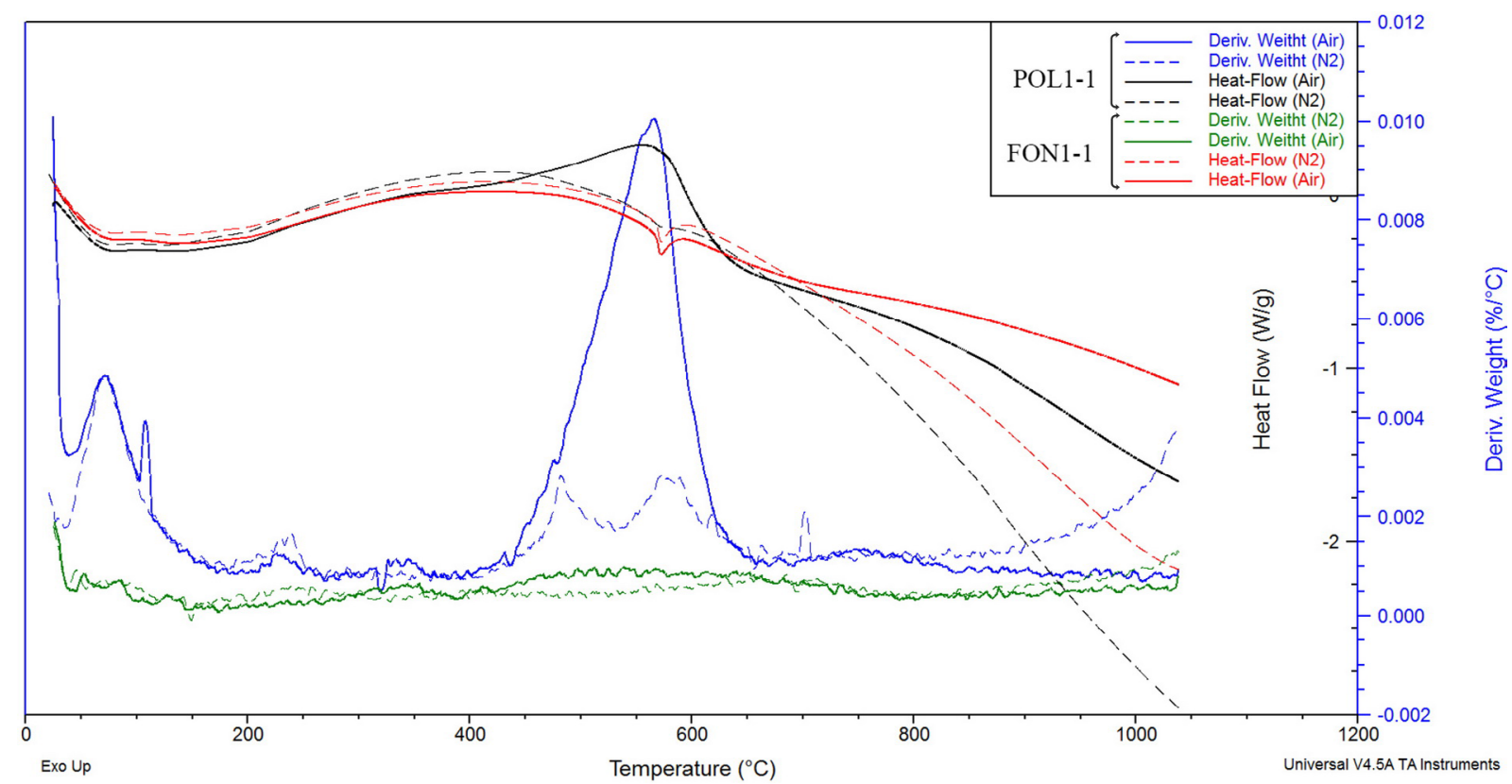

Figure 8: Thermogram of two samples, one type 1 (FON1-1) and another type 2 (POL1-1). In cherts of type 2 there is a loss of mass between $450^{\circ} \mathrm{C}-650^{\circ} \mathrm{C}$ that not appears in type 1 cherts. Around $575^{\circ} \mathrm{C}$ it is possible to see quartz- $\alpha$ to quartz- $\beta$ transformation. Loss of mass. POL1-1 2.09\% and FON1-1 0.53\%.

\section{Presence in sites}

Vegamián chert shares some similarities with some varieties of the 'black chert' indentified at the archaeological sites of La Uña and El Espertín (Neira et al. 2015). Both caves are located at the source of the Esla River, not far from the mountain passes that connect to the northern slope, although in different contexts. Whereas La Uña is located in the Esla valley itself, in an area with good visibility, 4.5-5 km from the Ventaniella pass, which gives access to the Ponga River, El Espertín instead is found in a secondary and orographically more secluded valley, providing it with less visibility and involving good knowledge of the area. The nearest pass connecting the northern slope is El Pontón, around 10 $\mathrm{km}$ away, representing the connecting way to the Sella River.

With regard to El Espertín, the closest primary-position cherts of the Vegamián Fm. (according to geological maps) are located about $8 \mathrm{~km}$ away as the crow flies (Figure 3). These outcrops, however, are located about 1800 m.a.s.l. and may have been difficult to access. Therefore, we must also consider deposits in a secondary position. Although a more thorough study is still needed, conditioned by the presence of the Riaño Reservoir, we should 
note that there are chert secondary-position deposits 15-20 km away from this same formation on a terrace of the Esla River (BHU1).

In terms of La Uña cave, the nearest outcrop (POL1) is just $4 \mathrm{~km}$ away, in a section cut by Becenes River from which it is easy to obtain nodules. Interestingly, this is not noted in the geological maps, which leads us to believe that there may be other outcrops closer to the cave that have yet to be located. What was mentioned earlier with regard to the supply in secondary deposits also applies in this case (the distance to BHU1 is slightly greater, 15-25 $\mathrm{km})$.

In the case of El Espertín, we have access to data from a thin-section study which identified two groups of black chert (Fuertes et al. 2010). Examining the thin sections allowed us to note similarities between sample 298, defined as "black laminated chert", and those pertaining to the Vegamián Formation, especially those found in a secondary position (BHU1-2 and BHU1-6), all Type 1. The similarities found were: lenticular lamination, grain size, occurrence of radiolarians and stylolites perpendicular to the plane of sedimentation (Figure 9).

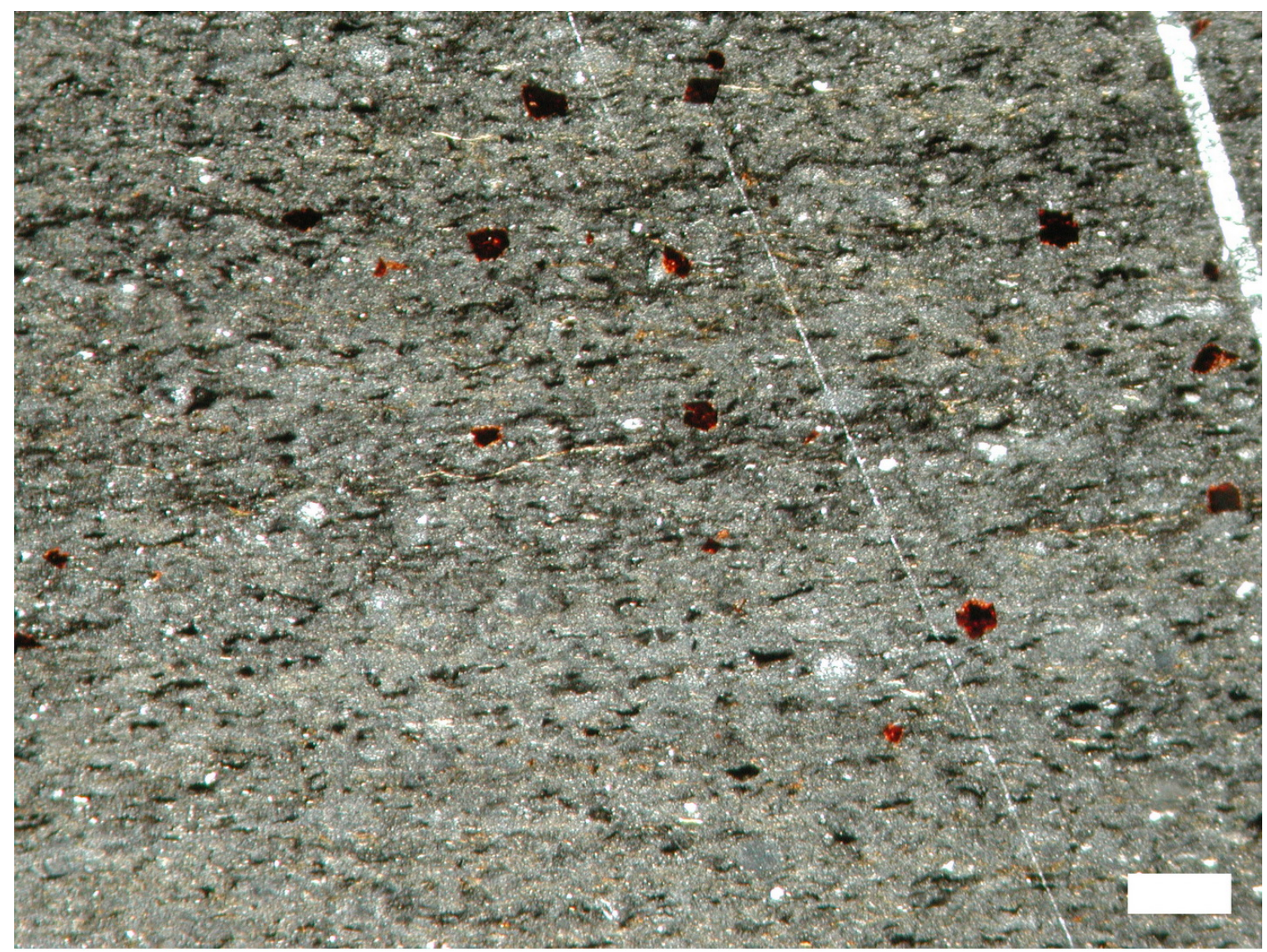

Figure 9: Detail of the matrix of sample 298 from El Espertín at 40x (xpl). Organic matter accumulations and some pyrites can be noted. (Scale bar $=250 \mu \mathrm{m})$ (Source: Fuertes et al. 2010)

In addition, in this comparison we were able to confirm that the remaining thin sections attached to "black laminated chert" from El Espertín (B1.13, G8N1) are compatible with the VQT1 samples (secondary position).

The study of La Uña cave is in its early stages of research and therefore no thin section of the archaeological material are currently available for comparisons to be made. Nevertheless, black cherts samples from this site have already been analysed using a stereo microscope, and 
important similarities with the Vegamián chert have been noted. Therefore, it is likely that this type of raw materials is part of this site's chaîne opératoire. We must, however, still wait for confirmation using the methodology proposed in this paper.

\section{Discussion and conclusions}

In the present study, we have characterised the chert pertaining to the Vegamián Fm., one of the siliciclastic formations that fall within the wide 'Carboniferous black chert' group (sensu Tarriño et al. 2015), from the central zone of the Cantabrian Mountains. These cherts are suitable for lithic knapping, are suitably sized and have conchoidal fractures, despite the presence of fracture planes.

In order to carry out this characterisation we have followed an analytical protocol including the petrological study of thin sections, XRD, XRF, ICP-OES and TG-DSC. The application of the latter technique, which has confirmed the results obtained from the XRD and XRF analyses, has expanded the information obtained and made up for some of the shortcomings of the other techniques. Therefore, and pending future analyses, TG-DSC is a new technique worth consider when studying chert.

Thanks to these analyses two varieties of chert of the Vegamián Formation have been identified, identifiable too at the macroscopic level. Type 1 (Table 6), of better quality in terms of knapping, has been identified in two primary sources (FON1, MUG1) and in a secondary position deposit in the Esla's upper basin (BHU1). Type 2, of lesser quality for knapping, has thus far only been identified in primary position outcrops.

The main characteristics of Vegamián chert are:

- Very dark colours, ranging between black (GLEY1 2.5/N) and grey (GLEY 3/N)

- Random lenticular laminated matrix.

- Occurrence of radiolarians (visible only in thin section and exceptionally under stereoscope microscope), pyrites and stylolites perpendicular to the plane of sedimentation.

- Abundant fracture planes in roughly cemented conjugated systems.

- High content of silica, over 97\% in Type 1 and around 92\% in Type 2.

- Content of felspar and micas as minority elements.

- Thin cortex in both primary and secondary deposits. Only nodule morphology differs (prismatic plaques in a primary context and rounded nodules in secondary context).

- Absence of white patina.

Table 6: Diagram of the black chert varieties and their occurrence in different contexts and from El Espertín cave (Source: Fuertes et al. 2010)

\begin{tabular}{lccc}
\hline Black chert types & $\begin{array}{c}\text { Primary } \\
\text { source }\end{array}$ & $\begin{array}{c}\text { Secondary } \\
\text { deposit }\end{array}$ & $\begin{array}{c}\text { Archaeological thin sections } \\
\text { from El Espertín }\end{array}$ \\
\hline Vegamián chert type 1 & FON1 & BHU & 298 \\
Vegamián chert type 2 & PVG1 & - & - \\
& POL1 & & \\
& SHC1 & & B1.13 \\
"Laminated black chert" & OLL1 & VQT1 & G8N1 \\
(unknown source) & - & DAM1 & \\
& & ARE1 & \\
\end{tabular}


The use of Vegamián chert at the Mesolithic site of El Espertín has been confirmed through the study of thin sections. Two separate lithologies classed under the 'black laminated chert' group defined at this site (Fuertes et al. 2010) have been identified as a result of this analysis (Table 6). The first (sample 298) corresponds to Type 1 Vegamián chert as defined in the present paper. The second (samples B1.13, G8N1) matches some samples from secondary deposits in the upper and mid basins of the Esla and Cares (RÑO1, VQT1, DAM1, ARE1). It is a variety the origin of which remains to be pinpointed. In the case of La Uña, the macroscopic characteristics of some of the cherts are compatible with those of Vegamián chert, which must be confirmed through future analyses.

Furthermore, in the Cenozoic sedimentary cover (North Iberian Plateau) there are sites from recent prehistoric times (Chalcolithic to Iron Age) with black chert lithic industries (Fuertes Prieto et al. 2015) that are macroscopically compatible with Vegamián Fm. Moreover, some Palaeolithic sites on the north versant of the Cantabrian Mountains also contain black chert collections, which could be similar to those from Vegamián Fm. (Arias et al. 2009, Álvarez-Alonso et al. 2013). However, it is necessary to carry out a more thorough study to confirm the use of Vegamián Fm. chert at those sites.

As discussed above, river basins have shown to be interesting supply sources in this area. Black chert nodules from different formations appear together in these contexts. The macroscopic characteristics are very similar and distinguishing between the different varieties is only possible through analytical procedures such as petrography and the mineralogical, geochemical and thermal analysis of the samples. Thus, of the four secondary deposits containing possible Vegamián chert (macroscopically), only one contains nodules from this formation (BHU1) (Figure 3).

Work on the characterisation of this formation must continue until chert from other outcrops and their secondary position distribution can be defined. It is also necessary that we continue searching for the location and characterising of other formations with silicifications within the Cantabrian Zone. This will lead to our knowledge on the potential lithic base of this area to be complete, which can then be used to compare it against the materials used in archaeological contexts.

\section{References}

Alonso, J.L., Suárez, A., Rodríguez Fernández, L.R., Farias, P. \& Villegas F.J. 1988, La Pola de Gordón (no.103, scale 1:50.000). Instituto Tecnológico Geominero de España, Madrid. (in Spanish)

Álvarez-Alonso, D., Andrés Herrero, M. de \& Rojo Hernández, J. 2013, La captación de materias primas líticas durante el Paleolítico en el Oriente de Asturias y su caracterización litológica en la cuenca de los ríos Sella y Cares (Asturias, España). In: VIII Reunión de Cuaternario Ibérico, La Rinconada - Sevilla 2013 (Baena, R., Fernández, J.J. \& Guerrero, I. Eds.), AEQUA, Sevilla: p. 296-299. (in Spanish) (“Lithic raw material procurement in the Palaeolithic of eastern Asturias and lithic characterization in the basin of Sella and Cares Rivers (Asturias, Spain)”)

Aramburu, C. \& Bastida, F. 1995, Geología de Asturias. Ediciones TREA, Gijón, 313p. (in Spanish) ("Geology of Asturias") 
Arias Cabal, P., Fernández, P., Marcos, C. \& Rodríguez, I. 2009, The elusive flint: raw materials and lithic technology in the Mesolithic of eastern Asturias, Spain. In: Mesolithic Horizons: Papers Presented at the Seventh International Conference on the Mesolithic in Europe Belfast 2009 (Woodman, P. \& Schulting, R., Eds.), Oxbow Books, Oxford: p. 860-672.

Bastida, F. (coord.) 2004, Zona Cantábrica. In: Geología de España (Vera, J.A. Ed.). Instituto Geológico y Minero de España, Madrid: p. 25-49. (in Spanish) (“Cantabrian Zone”)

Chung, F.H. 1974, Quantitative Interpretation of X-ray Diffraction Patterns of Mixtures. I. Matrix-Flushing Method for Quantitative Multicomponent Analysis. Journal of Applied Crystallography, 7(6): 519-525. doi:10.1107/s0021889874010375

Comte, P. 1959, Recherches sur les terrains anciens de la Cordillère Cantabrique, Memorias del Instituto Geológico de España, Madrid, 440 p. (in French) ("Research on the old grounds of Cantabrian Mountains”)

Evers, H.J. 1967, Geology of the leonides between the Bernesga and Porma Rivers, Cantabrian Mountains, NW Spain. Leidse Geologische Medelingen, 41: 83-151. URL: http://www.repository.naturalis.nl/record/505813

Fuertes Prieto, M.N. 2004, Estudio tecnológico de las industrias líticas del Paleolítico Superior y del Epipaleolítico de la cuenca del Duero. PhD Thesis, Faculty of Philosophy and Literature, University of León, León, 746 p. (in Spanish) ("Technological study of lithic industries of Upper Palaeolithic and Epipalaeolithic of Duero Basin”) URL: https://www.academia.edu/2013271/

Fuertes Prieto, M. N., Neira Campos, A., Gómez Fernández, F., Alonso Herrero, E. \& Fernández Martínez, E. 2010, Caracterización de las materias primas líticas del yacimiento Mesolítico de El Espertín (León), In: Minerales y rocas en las sociedades de la Prehistoria (Domínguez-Bella, S., Ramos Muñoz, J., Gutiérrez López, J.M. \& Pérez Rodríguez, M., Eds.), Grupo de Investigación HUM-440, Universidad de Cádiz, Cádiz: p.169-184. (in Spanish) ("Characterization of lithic raw materials from the Mesolithic site of 'El Espertín’ (León, Spain)")

Fuertes-Prieto, M. N., Neira Campos, A., Fernández Martínez, E., Gómez Fernández, F. \& Alonso Herrero, E. 2014, "Mucientes Chert" in the Northern Iberian Plateau (Spain). Journal of Lithic Studies, 1(1): 117-135. doi:10.2218/jls.v1i1.785

Fuertes Prieto, M. N., Neira Campos, A., Fernández Martínez, E., Gómez Fernández, F., Herrero Alonso, D. \& Alonso Herrero, E. 2015, El «sílex» en el sector noroccidental de la Meseta norte : Recursos litológicos aprovechados en la Prehistoria. Férvedes, 8: 4554. (in Spanish) ("The 'flint' in the northwestern sector of the northern Meseta: Lithological resources used in prehistory”)

Hatakeyama, T. \& Liu, Z. 1998, Handbook of thermal analysis. John Wiley and Sons, Chichester, 452p.

Herrero, D. 2014, El nivel III de la cueva de La Uña (Acebedo, León): Análisis tecnológico de la industria retocada y aprovisionamiento de materias primas. CKQ (Estudios de Cuaternario / Kuaternario Ikasketak / Quaternary Studies), 4:15-26. (in Spanish) (“The layer III of La Uña cave (Acebedo, León): technology analysis of retouched industry and supply of raw materials”) 
Julivert, M. 1971, Décollement tectonics in the Hercynian Cordillera of the northwest Spain. American Journal of Science, 270: 1-29. (in French) ("Variscan tectonics detachment in the Mountains of the northwest Spain”) doi:10.2475/ajs.270.1.1

Kanis, J. 1955, Geology of the eastern zone of the Sierra del Brezo (Palencia-Spain). Leidse Geologische Medelingen, 21: 377-445.

URL: http://www.repository.naturalis.nl/record/505760

Lobato, L., García-Alcalde, J.L., Sánchez de Posada, L.C., Truyols, J. \& Rodríguez Fernández, L.R. 1979, Boñar (no.104, scale 1:50.000). Instituto Geológico y Minero de España, Madrid. (in Spanish)

Marcos, A. 1967, Estudio geológico del reborde NW de los Picos de Europa (Región de Onís, Cabrales, Cordillera Cantábrica). Trabajos de Geología, 1: 39-46. (in Spanish) (“Geologic study of NW of Picos de Europa (Onís, Cabrales, Cantabrian Mountains”) URL: http://www.unioviedo.es/reunido/index.php/TDG/article/view/2656

Martínez-Chacón, M.L., Menéndez-Álvarez, J.R., Sánchez de Posada, L.C. \& Truyols, J. 1985, Aportaciones al conocimiento de la formación Ricacabiello (Carbonífero de la zona Cantábrica, N de España) y su contenido paleontológico. Trabajos de Geología, 15: 53-65. (in Spanish) ("Contributions to the knowledge of the Ricacabiello Formation (Carboniferous of the Cantabrian area, northern Spain) and its paleontological content”) URL: http://www.unioviedo.es/reunido/index.php/TDG/article/view/2797

Martínez-Díaz, C. 1983, Carbonífero y Pérmico de España. Instituto Geológico y Minero de España, Madrid, 502 p. (in Spanish) (“Carboniferous and Permian of Spain”)

Munsell Color 2013, Munsell soil-color charts: with genuine Munsell color chips (2009 Edition). Grand Rapids, Minessotta.

Neira, A., Fuertes, N. \& Herrero, D. 2015, The Mesolithic with geometrics south of the 'Picos de Europa' (Northern Iberian Peninsula): The main characteristics of the lithic industry and raw material procurement. Quaternary International, 402: 90-99. doi:10.1016/j.quaint.2015.10.065

Randon, C. \& Caridroit, M. 2008, Age and origin of Mississippian lydites: examples from the Pyrénées, southern France. Geological Journal, 43(2-3): 261-278. doi:10.1002/gj.1101

Rodríguez Fernández, L.R., García-Alcalde, J.L. \& Menéndez-Álvarez, J.R. 1983, La sucesión del Devónico superior y Carbonífero inferior en el Sinclinal de Alba (León, N.O. de España). In: Dixième Congrès International de Stratigraphie et de Géologie du Carbonifère (instituto Geológico y Minero de España, Ed.), Madrid, p. 133-144. (in Spanish) ("The Upper Devonian and Lower Carboniferous succession in the Syncline Alba (León, N.O. of Spain)”)

Savage, J.F. \& Boschma, D. 1980, Geological maps of the southern Cantabrian Mountains (Spain). Leidse Geologische Medelingen, 50(2): 75-114.

Straus, L.G., Clark, G.A., Ordaz, J., Suárez, L. \& Esbert R. 1986, Patterns of lithic raw material variation at La Riera. In: La Riera Cave: Stone Age hunter-gatherer adpations in northern Spain (Straus, L.G. \& Clark, G.A. Eds.), Anthropological Research Papers Vol. 36, Arizona State University, Tempe: p. 189-208.

Suárez, A., Barba, P., Heredia, N., Rodríguez Fernández, L.R., Fernández, L.P., Alonso, E., Nozal, F. \& Gallastegui, G. 1994, Mapa Geológico de la Provincia de León (escala 1:200.000). Instituto Tecnológico Geominero de España, Madrid, 180 p. (in Spanish) (“Geologic map of León province (scale 1:200.000)”) 
Tarriño, A. 1998, Rocas silíceas sedimentarias. Su composición mineralógica y terminología. Krei, 3: 143-161. (in Spanish) (“Sedimentary siliceous rocks: Mineralogical composition and terminology”)

URL: https://dialnet.unirioja.es/servlet/articulo?codigo=2733229

Tarriño, A., Elorrieta, I. \& García Rojas, M. 2015, Flint as raw material in prehistoric times: Cantabrian Mountain and Western Pyrenees data. Quaternary International, 364: 94108. doi:10.1016/j.quaint.2014.10.061

Wagner, R.H., Winkler Prins, C.F. \& Riding, R.E. 1971, Lithostratigraphic units of the lower part of the carboniferous in northern Leon, Spain. Trabajos de Geología, 4: 603-663. URL: https://www.unioviedo.es/reunido/index.php/TDG/article/view/2688 